\title{
Correspondence
}

\section{Public Process and State-Court Rulemaking}

To the Editors:

Professor Hazard, in his review of Judge Jack Weinstein's Reform of Court Rule-Making Procedures, ${ }^{1}$ finds the judge's proposed reforms of federal rulemaking procedure to be "restrained to the point of being exiguous." 2 Yet, Professor Hazard fails to mention Judge Weinstein's attack on unfettered judicial rulemaking in the state courts, that is, state-court rulemaking free from subsequent legislative intervention. ${ }^{3}$ This failure is noteworthy. Whatever the virtues of the status quo in the federal context, the sweeping scope of judicial autonomy in many state-court rulemaking procedures renders Judge Weinstein's call for more "public process" ${ }^{4}$ especially apt in the state context. The frequent insulation of state-court rulemakers from both the legislature and the electorate underscores the need for new modes of public participation in state rulemaking, particularly when state courts exercise quasi-legislative authority, as, for example, in regulating the practice of law.

Before proceeding to explore this topic, it should be noted that Judge Weinstein's description of state rulemaking suffers from several factual inaccuracies. In one instance, the autonomy of a judiciary's rulemaking power is exaggerated. Florida is said to be "one of four states whose constitution does not seem to subject judicial rule-making power to legislative control."s Yet a 1972 revision of the Florida constitution now permits procedural rules adopted by the Florida Supreme Court to be repealed by a two-thirds vote in both houses of the state legislature. ${ }^{6}$ More often, however, Judge Weinstein understates the extent of judicial autonomy in state rulemaking. For example, Judge Weinstein fails to note that many more than four state constitutions expressly grant state high courts at least some rulemaking

1. J. Weinstein, Reform of Court Rule-Making Procedures (1977).

2. Hazard, Book Review, 87 YALE L.J. 1284, 1287 (1978).

3. See J. WeINSTEIN, supra note 1 , at $82-83$.

4. Id. at 87. Judge Weinstein's treatment of the federal apparatus may also raise questions. For example, although he recognizes that the Judicial Conference engages in some quasi-rulemaking, see id. at 137 , the stronger claim could be made that Congress has delegated some unfettered rulemaking authority to the Conference, see 28 U.S.C. $\$ 604$ (1976) (mandating that Judicial Conference supervise all administrative matters relating to Article III courts). Further, Judge Weinstein suggests that Congress's ultimate authority over federal rulemaking power is complete and unproblematic. See J. WEINSTEIN, supra note 1, at 90. But query whether the Supreme Court could not question a congressional exercise of rulemaking power where the Court possesses original jurisdiction under Article III, $\S 2$, since such jurisdiction is compelled explicitly by the Constitution rather than left to Congress's discretion.

5. J. WeINSTEIN, supra note 1 , at 82.

6. FLA. Const. art. 5, § 2(a) (adopted Mar. 4, 1972). The Florida Supreme Court exercises exclusive rulemaking authority over admission to the practice of law. Id. $\S 15$. 
powers that lie beyond final legislative control. ${ }^{7}$ In addition, the trend over the past two decades has been toward placing more final rulemaking authority in state judiciaries ${ }^{8}$ and not, as Judge Weinstein suggests, ${ }^{9}$ toward vesting ultimate responsibility for rulemaking in state legislatures.

These factual inaccuracies might be unimportant were it not that Judge Weinstein also miscalculates the significance of autonomous judicial control of rulemaking procedures in the states. When Judge Weinstein examines a state in which the judiciary exercises absolute rulemaking authority, he finds "the same practical balance in rule-making as [in] other American jurisdictions."10 In his view, the practical need to bridge the formal separation of powers in state governments has made talk of unfettered judicial rulemaking authority "illusory." 11 This position has some basis, for one study suggests that even where state judiciaries exercise rulemaking authority that is immune from legislative veto, legislatures still retain some ability to affect judicial rules. ${ }^{12}$ Nevertheless, the ability to affect judicial rules falls well short of the ultimate power to determine judicial rules. ${ }^{13}$ Recent

7. Such powers involving rules of procedure can be found, for example, in ARIz. Const. art. 6, $\$ 21$ (effective 1965); Kx. Const. $\$ 116$ (effective 1976). Powers involving rules regulating the practice of law can be found, for example, in ARk. Const. amend. 28 (cffective 1938); IND. Const. art. 7, $\$ 4$ (effective 1970). And, such powers involving superintendence or administrative control can be found, for example, in CoLo. Const. art. 6, $\$ 21$ (effective 1965); Mrch. CoNsr. art. 4, $\$ 4$ (effective 1963). Other state constitutions have been read to grant unfettered rulemaking authority to the state's highest court. See, e.g., State v. McCoy, 94 Idaho 236, 486 P.2d 247 (1971) (interpreting IdAHo Const. art. 5, $\$ 13$ ); Southwest Underwriters v. Montoya, 80 N.M. 107, 452 P.2d 176 (1969) (interpreting N.M. Const. art. $3, \S 1$ ).

8. See note 7 supra; Dodge \& Cashman, The ABA Model Judicial Article, State Court J., Winter 1979, at 43 .

9. J. WEINSTEIN, supra note 1 , at 78-79.

10. Id. at 82 .

11. Id. Notwithstanding this illusion, Judge Weinstein cites a commentator who criticized the Connecticut Supreme Court for making "extravagant claims of exclusive power over rules." Id. $79-80$ (citing Kay, The Rule-Making Authority and Separation of Powers in Connecticut, 8 Cons. L. REv. 1 (1975)). Even if commentators were able to transform reality into illusion, the commentator in question had no such intent. See Kay, supra, at 41-42 ("the constitutional law of Connecticut appears to have established the final and complete authority of the supreme and superior courts to establish their own rules of procedure") (citation omitted).

12. See Ashman, Measuring the Judicial Rule-making Power, 59 Jub. 215, $219-20$ (1975).

13. Judge Weinstein underplays this difference in the scope of legislative power over judicial rulemaking. He repeats the dubious observation of an earlier commentator that, among the states, the ascendant policy is one of judicial rulemaking authority limited by ultimate accountability to the legislature. J. WEINSTEIN, supra note 1 , at 78-79 (quoting Kaplan \& Green, The Legislature's Relation to Judicial Rule-Making: An Appraisal of Winberry v. Salisbury, 65 HARv. L. REv. 234, 251 (1951)). But see note 7 supra (citing constitutional provisions vesting ultimate rulemaking authority in judiciary).

By overlooking the continuing vitality of unfettered judicial rulemaking, Judge Weinstein may misinterpret Wigmore's position. See J. WEINSTEIN, supra note 1, at 79 (“[n]o serious student would today accept Wigmore's thesis that the legislature has no power to affect judicial procedure"). Wigmore did assert at one point that "all legislatively declared rules for procedure . . . are void, except such as are expressly stated in the Constitution." Wigmore, All Legislative Rules for Judiciary Procedure are Void Constitutionally, 23 ILL. L. REv. 276, 276 (1928) (emphasis in original). Yet in the same piece, Wigmore acknowledged that legislatively declared procedural rules have "such effect as the comity of the 
events indicate the state judiciaries can, and will, block legislative attempts to subvert ultimate judicial authority in rulemaking. ${ }^{14}$

In 1976, the Michigan legislature passed an Open Meetings Act ${ }^{15}$ that provided for greater public access to governmental bodies. The Act specifically applied to "a court while exercising rule-making authority and while deliberating or deciding upon the issuance of administrative orders."16 However, shortly after the Act took effect, the Michigan Supreme Court, in a direct address to the legislature, declared that the portion of the Act dealing with the judiciary constituted "an impermissible intrusion into the most basic day-to-day exercise of the constitutionally derived judicial powers," which included "rule-making, supervisory and other administrative powers as well as traditional adjudicative ones."17

Tennessee provides a second example of a state judiciary successfully retaining ultimate authority over the judicial rulemaking process. In March 1978, Tennessee voters rejected a judicial article that would have limited the supreme court's rulemaking power by requiring legislative concurrence before judicial rules became effective. ${ }^{18}$ However, even if the voters had approved the proposed article, it is not certain that they would have succeeded in constraining the absolute rulemaking authority of the Tennessee Supreme Court. Chief Justice Henry strongly criticized the proposal on the ground that "[i]t did not lie within the power of the constitutional convention to strip any branch of government of its co-equal status nor to render its operation so ineffectual that it would cease to exist as an independent branch of our state's government."10

The continuing vitality of unfettered judicial rulemaking in some states has an important implication for Judge Weinstein's call for greater public process in judicial rulemaking; in many instances, the power to reform state rulemaking procedures lies exclusively in the hands of state high courts. Fortunately, however, state courts may be receptive to public participation

judiciary may give them in the absence of any rule made by the judiciary." Id. at 279. Thus Wigmore recognized legislative power to affect rulemaking, although this power was constrained by accountability to the judiciary.

14. What constitutes a legislative attempt to undermine a court's ultimate authority will depend on the extent to which that ultimate authority is exclusive. See Kaplan \& Green, supra note 13, at 250 ("Whatever ... the precise limits on the legislature's power, to assert that it may not stop . . . rule-making by blanket legislation is different from asserting . . . it cannot effectively repeal or modify particular court rules and . . . cannot act effectively, except by the court's sufference, in an area... left untouched by the rules.")

15. Míh. CoMp. Laws ANN. $\$ \S 15.261-.275$ (Supp. 1978).

16. Id. $\$ 15.263(7)$. What better way to make rulemaking a "public process?" See J. WEINSTEIN, supra note 1 , at 87.

17. In re 1976 PA 267, 400 Mich. 660, 663, 255 N.W.2d 635, 636 (1977). This was only the third time in the state's history that the supreme court was motivated "to communicate directly" about legislative action profoundly affecting the court. Id. at 661,255 N.W.2d at 636. The Act was passed despite the Michigan Supreme Court's laudable prior efforts to open up judicial decisionmaking on rules and administrative orders. See id. at 663,255 N.W. $2 \mathrm{~d}$ at 637.

18. See Tennessee votes to reject proposal for new judicial article, 61 JuD. 431, 431 (1978).

19. Id. See generally Sweet, Anatomy of a "Court Reform," 62 JuD. 37 (1978) (describing genesis, content, and defeat of proposed Tennessee judicial article). 
in the formulation of judicial rules. In North Dakota, for example, the supreme court recently invoked its newly granted, absolute rulemaking authority ${ }^{20}$ to promulgate two rulemaking procedures-one governing its own rulemaking process ${ }^{21}$ and the other regulating local rulemaking by the lower courts.22 Both mechanisms sanction broad participation by all persons interested in judicial rules. ${ }^{23}$ Indeed, these court-established procedures may prove more effective in providing public access to the rulemaking process than earlier procedures instituted by the state legislature. ${ }^{24}$

The North Dakota experiment demonstrates that judicial rulemaking, unfettered by other branches of government, may be consistent with greater public process in state rulemaking. However, this indication of judicial receptivity also raises a series of broader questions surrounding public participation in rulemaking procedures-questions that both Judge Weinstein and Professor Hazard consider only in the context of federal rulemaking.

A first question concerns the kind of judicial rule that ought to be the subject of public deliberation and debate. ${ }^{25}$ Certainly some rules merit less public participation than others. For example, emergencies may on occasion require the immediate promulgation of a rule without any public process; ${ }^{26}$ in addition, narrow, technical rules obviously have less claim to formal public deliberation than rules affecting "sensitive issues of social policy."27

20. N.D. Const. art. $4, \S 87$.

21. R. P.R., Ad. R. \& AD. Orders N.D. Sup. CT. (adopted Mar. 15, 1978) (on file with Yale Law Journal) [hereinafter cited as N.D. Sup. CT. R.]; see 62 Jud. 101 (1978) (general description of North Dakota rules).

22. N.D. LocAL Cr. R. (adopted Mar. 15, 1978) (on file with Yale Law Journal).

23. For example, $\S 3.1$ of both procedures, see notes $21 \& 22$ stpra, provides that "[a]ny person interested ... may file . . a petition to adopt, amend, or repeal" a procedural or administrative rule.

24. For example, N.D. CENT. CoDE $\$ 27-02-11$ (1974) requires the high court, inter alia, to mail to all attorneys copies of any proposed rules relating to either the practice of law or to pleading, practice, and procedure.

25. This discussion excludes rules established during the course of litigation, e.g., prudential rules of standing or abstention in the federal context. See generally ALI, Study of the Division of Jurisdiction Between State and Federal Courts 49 (1969) (suggesting statutory revision and formalization of abstention rules).

26. See, e.g., N.D. Sur. CT. R., supra note 21 , § 6.1; N.D. Local CT. R. $\$ 6.1$.

27. See Wright, Book Review, 9 ST. MARY's L.J. 652, 656 (1978). Rules affecting sensitive issues of social policy include those on attorney advertising and solicitation, unauthorized practice of law, judicial conduct, class actions, and televised courtroom proceedings. Professor Wright seemingly favors leaving sensitive issues of social policy to the legislatures. See id.

Besides the special claim to public debate exercised by rules touching on sensitive policy issues, a distinction should be drawn between rules of practice and procedure and administrative rules bearing on internal court operations. Congress itself may have made such a distinction in the federal context. See note 4 supra. In addition, the same division appears in several state constitutions. For example, the Ohio constitution distinguishes between the state supreme court's duties in exercising "general superintendence" over lower courts, Онго CoNst. art. 4, $\$ 5(\mathrm{~A})(\mathrm{I})$, and the court's function in prescribing "rules governing practice and procedure" in lower courts, id. $\$ 5(\mathrm{~B})$. The Ohio high court has adopted different rulemaking procedures under these two powers. Compare Corrigan, $A$ Look at the Ohio Rules of Civil Procedure, 43 OHо ST. B.A. REP. 727, 728 (1970) (Rules 
A second question of particular importance in the state context concerns the consequences that the balance of rulemaking authority between the legislative and judicial branches should have for the nature of public participation in judicial rulemaking. The various state constitutions and statutes support not only unfettered judicial rulemaking, ${ }^{28}$ but, in many instances, judicial rulemaking constrained either by legislative veto power ${ }^{29}$ or by concurrent legislative rulemaking authority. ${ }^{30}$ Arguably, a broad legislative role in rulemaking diminishes the need for judicial creation of other modes of public participation, particularly when state legislatures provide a reliable forum for open debate. ${ }^{31}$

When the public lacks an effective legislative channel for participation in the rulemaking process, however, a final question concerns the selection of alternative channels for public participation. Experience suggests that these channels should vary with the range of potential participants and the nature of the rules under consideration. ${ }^{32}$ Advisory committees selected from among the ranks of the professional elite-the elite whose skills are

Advisory Committee assists court in developing procedural rules) with Preface to OHro R. CT. (Baldwin 1971) (Administrative Director assists court in promulgating Rules of Superintendence for Municipal Courts and County Courts).

28. Some judicial rulemakers possess both fettered and unfettered powers in different areas. Compare OHIo Const. art. $4, \S 5(\mathrm{~A})$ with id. $\S 5(\mathrm{~B})$.

29. The veto may require a majority vote, see MD. Const. art. $4, \S 18$; OHo Const. art. $4, \S 5(\mathrm{~B})$, or it may require a two-thirds vote, see AlAskA Const. art. $4, \S 15$; FLA. Const. art. $5, \S 2(a)$.

30. WIs. STAT. ANN. $§ 751.12$ (West Supp. 1978). This division of authority between legislature and judiciary is apparently working. See Supreme Court Order: Adoption of Rules Relating to the Office of Chief Judge, Judicial Administrative Districts and Assignment Judges, 51 Wis. B. Bull., Aug. 1978, at 31-32; Parness \& Korbakes, A Study of the Procedural Rulemaking Power in the U.S. 61 (Am. Jud. Soc'y mimeo 1973).

31. Formal legislative power to review rules does not necessarily imply that rules will in fact receive the open debate that they deserve. In Illinois, for example, the legislature failed to exercise fully its ultimate rulemaking authority for at least 10 years after that power was reaffirmed pursuant to a court-unification plan. See Parness \& Korbakes, supra note 30 , at 30 . Hearings and debate accompanying open legislative consideration provide the public a far greater opportunity to be heard than does the representative nature of legislative action itself.

32. North Dakota, for example, provides a broad spectrum of public notification devices that vest the right to receive notice in the executive committee of the state bar, trial-court judges, the chairpersons of the high court's advisory committees, the director of the Legislative Council, and the news media through the Associated Press. See N.D. Sup. CT. R., supra note 21, $\$$ 7.1. Potential participants in North Dakota's rulemaking process include "any person interested." Id. $\$ 3.1$. Other states are more exclusive. See NEv. R. AD. DOCKET $\S 3.2$ (listing participants in rulemaking process as "any judge, the Director of the Administrative Office of the Courts, or the Board of Governors of the State Bar") (on file with Yale Law Journal).

Both the scope of notice to potential participants in the rulemaking process and the form of their contribution should hinge on a series of relevant factors including costs to the state, the anticipated quality and magnitude of public response, the projected impact of the rules under consideration, and the likelihood of substantial legislative review. $C f$. 5 U.S.C. $\$ 553(c)$ (1976) (juxtaposing general agency rulemaking in which opportunity to participate embodies "submission of written data, views, or arguments with or without opportunity for oral presentation," and particular agency rulemaking procedures in which 
so amply celebrated by Professor Hazard in the federal context $\mathrm{t}^{33}-$ might be delegated the task of ensuring adequate levels of public participation in the formulation of most procedural rules. Similarly, committees selected from among state-judiciary administrative officers should exercise responsibility for uncontroversial rulemaking that focuses on court administration. By contrast, rulemaking that implicates sensitive issues of social policy $^{34}$ warrants well-publicized open hearings, and perhaps even hearings at multiple locations, in order to maximize accessibility to potential participants. Finally, the need for differentiated forms of public participation in state rulemaking suggests that the formalization of rulemaking procedures should also receive the careful attention of judicial rulemakers. Unless notice requirements, responsible officials, and the structure of public access to rulemaking procedures are clearly articulated, a differentiated approach to state rulemaking will generate uncertainty at best ${ }^{35}$ and, at worst, will reduce the very access that it attempts to facilitate. It is my hope that these few observations will help to spur the reform of all American rulemaking systems, now that Judge Weinstein has urged further dialogue.

\author{
Jeffrey A. Parness \\ Assistant Professor of Law \\ The University of Akron School of Law
}

rules are "required by statute to be made on the record after opportunity for an agency hearing").

In deciding on the appropriate scope of public participation and notice, state high courts should consider that increased legitimacy in the rulemaking process derives from public participation per se regardless of whether public contributions are likely to be politically viable. But cf. Hazard, supra note 2, at 1292 (suggesting that narrow range of politically viable proposals is ground for limiting participation in federal rulemaking process).

33. See Hazard, supra note 2, at 1294.

34. See note 27 supra.

35. In Ohio, for example, there are several modes of judicial rulemaking. See note 27 supra. Yet, since 1968, rules advisory committees have been appointed on a project-byproject basis, and thus have existed only by virtue of tradition and the grace of the court. See Letter to Author from Professor Stanley E. Harper, Jr. (July 18, 1978) (on file with author and Yale Law Journal). In addition, although proposed rules are published prior to promulgation in a bar association journal, no Ohio rule requires publication. See Letter to Author from Thomas L. Startzman, clerk of Supreme Court of Ohio (July 6, 1978) (on file with author and Yale Law Journal). Thus, even assuming that Ohio's advisory committees are open to public participation, effective opportunity to participate will depend on the unpublicized publication of a proposed rule and its subsequent discovery by would-be participants. 